\title{
Systems engineering for prevention- oriented, assistive technology situated in a multidisciplinary context
}

\author{
Thomas Linner Dr.-Ing. ${ }^{\mathrm{a}, *}$ \\ Rongbo Hu M. Arch. ${ }^{a}$ \\ Katja Pawlitza M. Arch. ${ }^{a}$ \\ Jörg Güttler M.Eng. ${ }^{\mathrm{a}}$
}

\begin{abstract}
${ }^{a}$ Chair of Building Realization and Robotics, Technische Universität München, Germany; *Corresponding author: thomas.linner@bri.arch.tu-muenchen.de
\end{abstract}

\begin{abstract}
T. Linner, R. Hu, K. Pawlitza, J. Güttler. Systems engineering for prevention-oriented, assistive technology situated in a multidisciplinary context. Gerontechnology 2017;16(3):129138; https://doi.org/10.4017/gt.2017.16.3.002.00 REACH states a complex system of systems that is not only developed by highly multi-disciplinary consortium, but moreover is situated in an environment comprised of a multitude of stakeholders (ranging from governments down to end-users) and external systems. Due to the criticality of personal data and the legal impact of medical, preventive feedback handled by $\mathrm{REACH}$, and considering later CE certification requirements. It is pertinent to follow even from very early, explorative, and conceptual R\&D or pre-product development phases onwards a structured systems engineering approach. In this paper, the key aspects, methods, and tools of this approach are presented, and it is shown how they were used in the concept development stage to systematically translate a variety of inputs and analyses (stakeholder workshops, user studies, use case analyses, technology analyses, etc.) into formalized requirements and a holistic system architecture blue print serving as the basis for further work organization in the project.
\end{abstract}

Keywords: assistive and preventive technology, systems engineering, system architecture development, requirements engineering

In REACH, a sensing-monitoring-intervention system is developed that can be placed in an unobtrusive manner in various care settings and living environments of elderly citizens. It states a complex system of systems that is developed by a highly multidisciplinary consortium (ICT partners, device partners, sociologists, care professionals, sociologist and human factor specialist, data scientists, etc.) where individual project partners (or sets of project partners) supply or develop the individual systems (e.g. Touchpoints) and sub-systems (e.g. sensors, data, devices, software, algorithms, services, etc.) that need to be integrated with each other.

Due to the criticality of personal data and the legal impact of medical, preventive feedback handled by $\mathrm{REACH}$, it is pertinent to follow a structured development approach even from very early, explorative R\&D phases onwards. This is particularly important when developing solutions for the health care markets where the use of a systematic development method is pertinent and beneficial to later CE certifi- cation requirements ${ }^{1}$. REACH flexibly utilizes and combines elements of the (1) V-Model approach, (2) Agile Management ${ }^{2,3,8}$, and the (3) NASA systems engineering approach (Figure 1). The $\mathrm{V}$-Model approach ${ }^{6}$ provides the general development and integration plan strategy. In this structure, as per the Agile Management Approach $^{5}$ small and short test with mock-ups of smaller parts of the systems (early testing, pretesting 1) are allowed to develop and emerge in an experimental manner the system's qualitative features. The NASA ${ }^{4}$ systems engineering approach is followed to develop and detail in a systematic manner the components' and interfaces' specifications and to plan with pretesting 2 and final testing the verification and validation of the system.

In this paper, the Design Concept development approach of REACH is presented. REACH is not only a multidisciplinary project, that is comprised of 17 partners with a variety of professional backgrounds and aims, but moreover is situated in an environment comprised of a 


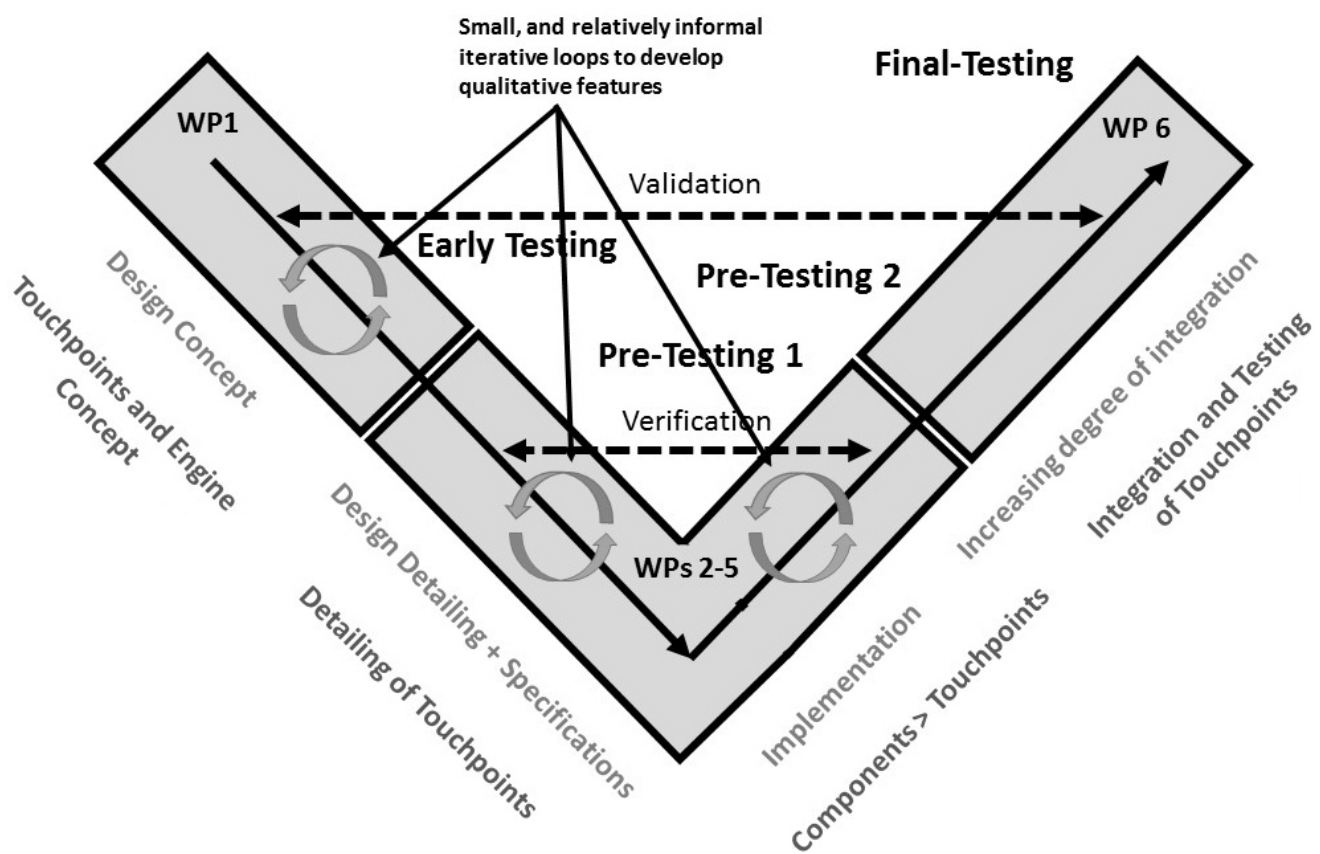

Figure 1. REACH flexibly utilizes and combines elements of the (1) V-Model approach, (2) Agile Management, and the (3) NASA systems engineering approach

multitude of stakeholders (ranging from governments down to end-users) and external systems to which REACH must connect. Thus, it was pertinent to develop and apply a REACHspecific method (Figure 2) for the translation of initial work outcomes (completed deliverables) into formalized requirements and a system architecture blueprint.

EXTRACTION, FORMALIZATION, AND STRUCTURING OF REQUIREMENTS FROM MULTIPLE SOURCES

In a requirements engineering process comprised of 3 phases, first, the requirements were extracted from multiple sources and formalized, then an initial detailing of the Touchpoints took place to form 'graspable' development entities, and finally the most important and formalized requirements were selected assigned to these development entities.

\section{Identification and formalization of raw re- quirements}

All outcomes of completed activities (stakeholder analysis; co-creation workshops with users; analysis of use cases, business models, technologies, etc.; first early trials and ethnographic and usability studies; development of privacy and data management approach; analysis of motivational

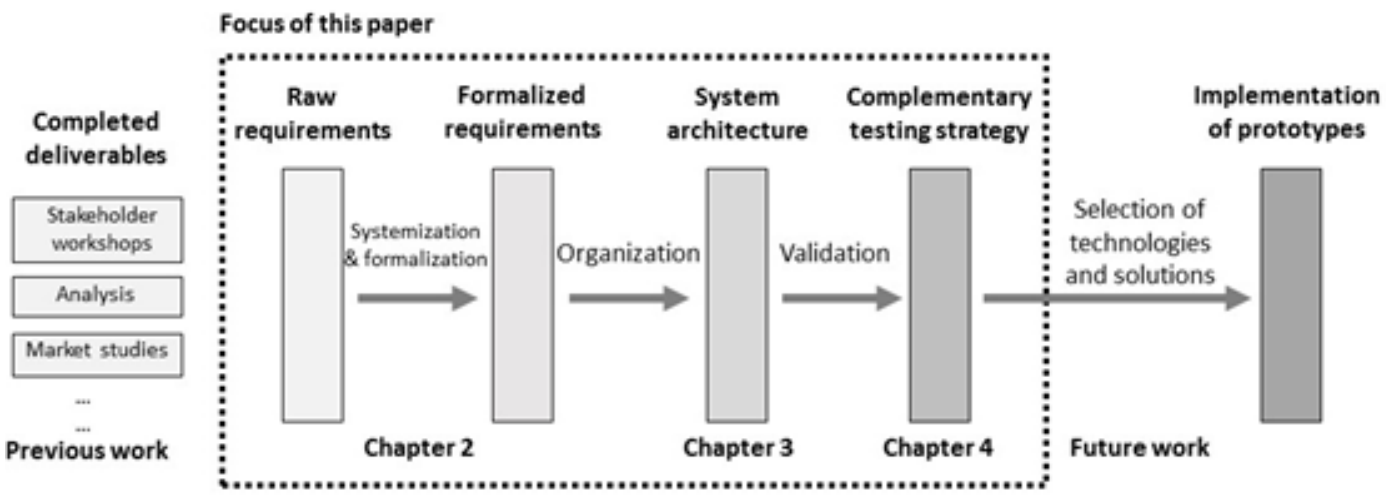

Figure 2. REACH specific method for the translation of initial work outcomes (completed deliverables) into formalized requirements and a system architecture blueprint 
Table 1. REACH requirements categories (REACH interpreted and took further the relatively detailed classification system introduced by Sparx Systems, n.d.

\begin{tabular}{|c|c|c|}
\hline Category name & ID & Description \\
\hline $\begin{array}{l}\text { Business, Market, and } \\
\text { Innovation Require- } \\
\text { ments }\end{array}$ & BMIR & Business-related requirements \\
\hline $\begin{array}{l}\text { Stakeholder Require- } \\
\text { ments }\end{array}$ & SR & $\begin{array}{l}\text { Needs of the end-users, the care institutions and health professionals, infor- } \\
\text { mal care givers, insurances, governments and technology providers }\end{array}$ \\
\hline $\begin{array}{l}\text { Functional System Re- } \\
\text { quirements }\end{array}$ & FR & Answer the question what the system shall be enabled to do \\
\hline $\begin{array}{l}\text { Non-functional Re- } \\
\text { quirements }\end{array}$ & NFR & Describe the properties that the system shall have \\
\hline $\begin{array}{l}\text { System Architecture Re- } \\
\text { quirements }\end{array}$ & SAR & $\begin{array}{l}\text { Deal with the requirements defining the conceptual organization of a system. } \\
\text { In the case of REACH, the Touchpoints/ Engine concept will be further de- } \\
\text { scribed }\end{array}$ \\
\hline $\begin{array}{l}\text { Project Implementation } \\
\text { Requirements }\end{array}$ & PIR & All conditions and features needed to realize/implement the prototypes \\
\hline $\begin{array}{l}\text { EU, Funding, and Call } \\
\text { related Requirements }\end{array}$ & EFCR & Requirements related to the $\mathrm{H} 2020$ funding program and its provisions \\
\hline $\begin{array}{l}\text { Regulatory Require- } \\
\text { ments }\end{array}$ & RR & Requirements related to legislation, guidelines, best practices, and standards \\
\hline $\begin{array}{l}\text { Data Management and } \\
\text { Ethics Requirements }\end{array}$ & $\mathrm{DM}$ & $\begin{array}{l}\text { Requirement to proper study design, general ethics compliance and integrity, } \\
\text { personal data protection and processing, and data management }\end{array}$ \\
\hline $\begin{array}{l}\text { Health Outcome Re- } \\
\text { quirements }\end{array}$ & HQR & $\begin{array}{l}\text { Requirements that express what results are expected at the end of the treat- } \\
\text { ments }\end{array}$ \\
\hline Transition Requiremen & & $\begin{array}{l}\text { Deal with what must be given to allow the patient a seamless transition from } \\
\text { one healthcare facilities to another }\end{array}$ \\
\hline
\end{tabular}

strategies; IP and stakeholder management, etc.) of the first major REACH project phase (project year one: concept phase) were systematically summarized, and key points and outcomes were selected and extracted (= raw requirements extraction). The extracted raw requirements were further formalized, i.e. (1) assigned to a requirements category, (2) reformulated using a systemized, category-adapted syntax, and (3) linked to a coding system (location, reference, ID) that allows to re-identify the origin and nature of each requirement. With regard to the identification of the requirements categories, the relatively detailed classification system ${ }^{7}$ was interpreted and took further (Table 1).

The structure of the lists of formalized requirements is explained in Table 2. The list is subdivided into 6 columns: requirement categories, raw requirement, formalized requirement, use case setting, reference, and ID. The requirements were extracted mainly from submitted work deliverables. The original wording of the requirement (as per the deliverable) was locat- ed in the column 'raw requirements' and then translated into a 'formalized requirement'. The corresponding work deliverables from where the requirements where extracted) are listed in the column 'reference'. The column 'use case setting' refers to the use case environment (clinic, home for the elderly, community centre, etc.) for which the requirement predominantly applies. Every requirement has an 'ID' that shows to which requirements category it belongs to. Table 3 provides in an exemplary manner an excerpt from the filled, final requirements list.

\section{Detailing of key system elements (Touch- points) by project-internal stakeholders}

The work teams around each Touchpoint were formed and reconfirmed with the consortium. The 'Touchpoints and Engine concept' now structures the envisioned REACH product-service-system architecture, into manageable research and development clusters. Touchpoints will mainly materialize as 'furniture' in a broader sense, which means elements that can be placed and moved within a certain environment or set-

Table 2. Structure of the requirements table

\section{Requirement categories}

Business, Market, and Innovation

Requirements ting (e.g. beds, bath furniture, mobile walkers/ standers, large scale interfaces, smart flooring tiles, smart tables, etc.). 5 
physical Touchpoints will each function as data gathering and intervention devices, which are bound together by cross-sectional, integrated engine (i.e. platform) functionality. For each Touchpoint 8 key points were clarified with the development group partners (Table 4).

\section{Assignment of formalized requirements to the key system elements}

Finally, highly important and formalized requirements were selected by the REACH consortium members and assigned to the individual Touchpoints. Figure 3 exemplarily shows the visualization guide plan of Touchpoint 1 and Table 5 outlines the selected, most important requirements for this Touchpoint. Based on this list each Touchpoint development group has now the freedom to interpret these requirements and find appropriate technological solutions (aligned with their competencies and skills) to address them.

\section{INITIAL SYSTEM ARCHITECTURE OUTLINE}

Based on the outcomes of the previously described requirement engineering process the overall linkage and coordination between these elements, i.e. the overall system architecture was detailed. As per ISO/IEC/IEEE 42010:2011, a system shall respond with its 'architecture' (which needs to be described) to its 'environment' and to 'concerns' (needs) of its stakeholders and requirements. From stakeholders and the environment context in the first project year of REACH various aspects have been analyzed and requirements have been derived for guiding the detailing of the REACH system architecture as well as each REACH sub-systems.

In REACH the 'Touchpoints and Engine concept' is considered as a system architecture high-level

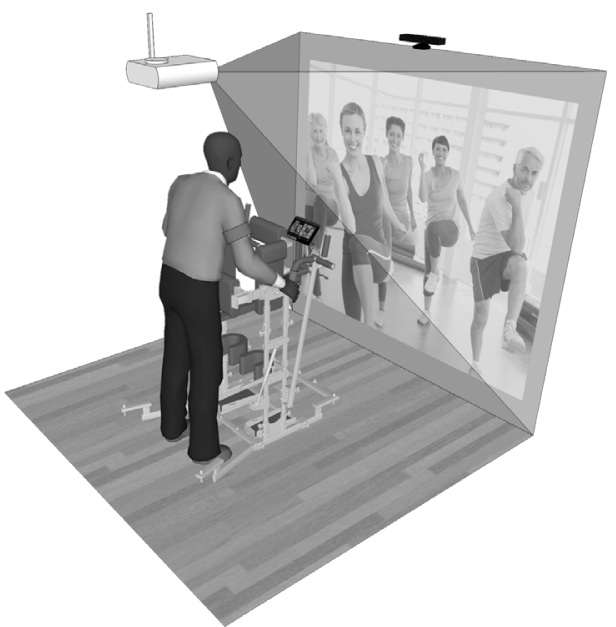

Figure 3. REACH 'Touchpoint 1 Personal Mobility Device' requirements description and will further guide the detailing of the REACH system architecture description. The 'Touchpoints and Engine concept' structures the envisioned REACH product-service-system architecture, into seven manageable research and development clusters, as following: five clusters of 'Touchpoints', which represent any tangible connection between users (seniors, informal/formal caregivers, physicians etc.) and the REACH system; one 'Engine' cluster, which represents the cloud based digital platform; and the 'interface' cluster, which represents a set of specifications that allows Touchpoints and other products/services to connect/interact with the Engine (Figure 4). Each research cluster is associated with a separate development team made of consortium members, with a team leader.

A system architecture description uses a certain or a variety of views (SAVs; see also ISO/ IEC/IEEE 42010) to describe the system (physical view, business, view, ICT view, etc.). In $\mathrm{REACH}$, a complex and multidimensional project, system architecture and the organization and relations of sub-systems needs to be described through various views. Within this views modeling techniques, which allow to graphically and hierarchically represent the system (e.g. module break down structure) are used. For REACH four SAVs were developed and detailed:

(i) SAV 1: ICT platform view-software and data migration architecture, and information flows) (ii) SAV 2: REACH Feedback-loop view-the relation between early detection, sensing, monitoring, motivation, and intervention

(iii) SAV 3: Physical view-physical modularity and Product breakdown structure

(iv) SAV 4: Business strategy view

Figure 5 graphically outlines the core elements described by the ICT view and Figure 6 outlines the physical view generated by using the product break down structure approach.

\section{DeVELOPMENT OF A COMPLEMENTARY SYSTEM INTE- GRATION AND TESTING APPROACH}

With the overall system architecture detailed and the first early trials completed, it became obvious that it is impractical to test each Touchpoint with regard to its complex, subsequent chain of early detection, motivational techniques, and programmed interventions in a single trial. Therefore, unrealistically large and long trials would be required which are beyond the scope and resources of the project. Instead, following a decomposition of the 'testing problem' was done. For each Touchpoint separate testing 'instances' were created and each of this testing instances represents a separate trial 
Table 3. Excerpt of the filled requirements table (Functional System Requirements)

\begin{tabular}{|c|c|c|c|c|}
\hline Raw requirements & Formalized requirements & $\begin{array}{l}\text { Use case } \\
\text { setting }\end{array}$ & Reference & ID \\
\hline $\begin{array}{l}\text { Motivate to participate in and } \\
\text { adhere to therapies/scheduled } \\
\text { trainings/interventions }\end{array}$ & $\begin{array}{l}\text { Touchpoint Active Environment } \\
\text { shall motivate patient to in and } \\
\text { adhere to therapies/scheduled } \\
\text { trainings/interventions }\end{array}$ & All & $\begin{array}{c}\text { D4 } \\
\text { Chapter } 3\end{array}$ & FSR031 \\
\hline $\begin{array}{l}\text { A combination and integration of } \\
\text { "furniture" components (bed + bed } \\
\text { periphery + mobility device } \\
\text { (iStander) + toileting support) to a } \\
\text { seamless in-house "transfer and } \\
\text { mobility chain" should facilitate a } \\
\text { significant increase of mobility in } \\
\text { the patient room }\end{array}$ & $\begin{array}{l}\text { Touchpoint Active } \\
\text { Environments shall increase } \\
\text { the mobility of the patient } \\
\text { through a combination and } \\
\text { integration of "furniture" } \\
\text { components to a seamless in- } \\
\text { house "transfer and mobility } \\
\text { chain" }\end{array}$ & All & $\begin{array}{c}\text { D4 } \\
\text { Chapter } 3\end{array}$ & FSR032 \\
\hline $\begin{array}{l}\text { Large scale interface: a large scale } \\
\text { interface in the patient room will } \\
\text { facilitate training instructions, } \\
\text { gamification, etc.) }\end{array}$ & $\begin{array}{l}\text { Touchpoint Active } \\
\text { Environments shall provide a } \\
\text { large scale interface to } \\
\text { facilitate training instructions, } \\
\text { gamification, etc. }\end{array}$ & All & $\begin{array}{c}\text { D4 } \\
\text { Chapter } 3\end{array}$ & FSR033 \\
\hline $\begin{array}{l}\text { Wearables will help to detect } \\
\text { general vital signs }+ \text { movements } \\
\text { such as getting out of bed }\end{array}$ & $\begin{array}{l}\text { Touchpoint Active } \\
\text { Environments shall use } \\
\text { Wearables to detect general } \\
\text { vital signs and movements }\end{array}$ & All & $\begin{array}{c}\text { D4 } \\
\text { Chapter } 3\end{array}$ & FSR034 \\
\hline $\begin{array}{l}\text { Ambien sensors: will detail overall } \\
\text { vital signs image + provide } \\
\text { detailed data for example about } \\
\text { postures, etc. }\end{array}$ & $\begin{array}{l}\text { Touchpoint Active } \\
\text { Environments shall use } \\
\text { ambient sensors to detail } \\
\text { overall vital signs }\end{array}$ & All & $\begin{array}{c}\text { D4 } \\
\text { Chapter } 3\end{array}$ & FSR035 \\
\hline $\begin{array}{l}\text { Develop motivational strategies } \\
\text { that facilitate the physical activity } \\
\text { levels within the context of } \\
\text { socialising and nutritional intake }\end{array}$ & $\begin{array}{l}\text { Touchpoint Socializing \& } \\
\text { Nutritional Monitoring + } \\
\text { Intervention shall develop } \\
\text { motivational strategies that } \\
\text { facilitate the physical activity } \\
\text { levels within the context of } \\
\text { socialising and nutritional } \\
\text { intake }\end{array}$ & All & $\begin{array}{c}\text { D4 } \\
\text { Chapter } 3\end{array}$ & FSR036 \\
\hline $\begin{array}{l}\text { The food nutrition/ food/ recipes/ } \\
\text { recommendations should make } \\
\text { them active (go shopping to get } \\
\text { ingredients, meet with others to } \\
\text { cook, etc.) }\end{array}$ & $\begin{array}{l}\text { Touchpoint Socializing \& } \\
\text { Nutritional Monitoring }+ \\
\text { Intervention shall make the } \\
\text { patient active through food } \\
\text { nutrition/food/recipes/recomm } \\
\text { endation }\end{array}$ & All & $\begin{array}{c}\text { D4 } \\
\text { Chapter } 3\end{array}$ & FSR037 \\
\hline $\begin{array}{l}\text { Facilitation of socializing and } \\
\text { nutritional intake should enhance } \\
\text { the physical activity level. }\end{array}$ & $\begin{array}{l}\text { Touchpoint Socializing \& } \\
\text { Nutritional Monitoring + } \\
\text { Intervention shall enhance the } \\
\text { physical activity level through } \\
\text { facilitating socialising and } \\
\text { nutritional intake }\end{array}$ & All & $\begin{array}{c}\text { D4 } \\
\text { Chapter } 3\end{array}$ & FSR038 \\
\hline
\end{tabular}

Development of receipts (and

shopping lists) that react on certain Touchpoint Socializing \& needs of elderly such as physical Nutritional Monitoring + activity levels, malnutrition, etc. Intervention shall develop Recipe development for breakfast, lunch, dinner and drinks (e.g. shakes) including the maximum enrichment and nutritional values of each recipe at different menu sizes receipts and shopping lists that react on certain needs of elderly, nutritional values of each recipe at different menu sizes etc.

All $\quad \begin{array}{ll}\text { D4 } & \text { FSR039 }\end{array}$


Table 4. Detailing Example; Touchpoint 1 Detailing: Personal Mobility Device

\section{T1 Cluster (Personal Mobility Device) Detailing Summary \\ TP leader: INDUSTRY PARTNER3; members of development team: INDUSTRY PART- NER3, RESEARCH PARTNER1, INDUSTRY PARTNER2 (+ RESEARCH PARTNER5 for de- tection algorithms); use cases/testing: APPLICATION COMMUNE/COMMUNITY CEN- TRE and UNIVERSITY HOSPITAL.}

\section{Early detection capability (what to early detect?)}

- Signs of frailty

- Person under risk of falls, risk of hospitalization, risk of needing long-term care

- Evolutionary approach: early detection will be done only with the sensors; when signs of frailty are detected, the professional caregivers will be alerted and, when appropriate, the mobility device comes in as a safe activation and training device. The mobility device optimally follows (and can modularly be adapted to) the person throughout the patient journey through different care stages.

- First ideas regarding the sensing approach:

- Identification of the frailty and/or risk of falls level or risk through measuring of activity levels and trends (e.g. INDUSTRY PARTNER2 armband)

- Identification of the frailty and/or risk of falls level or risk through breath measured through the Kinect sensor (alternatively: heart rate measurement)

- Detection of context, presence, or the activity (ADL) performed by the user in the environment (location sensors)
pects

\section{Motivational aspects}

- $\quad$ The goal is to motivate the elderly (e.g. through gamification) to use the equipment to train a) themselves, b) or in a community (e.g. a COMMUNITY (ENTRE), or c) together with care personnel in an institution to achieve a better level of mobility.

- $\quad$ At best, this results in an improved mobility, e.g. in terms of distances walked (also without using the equipment).

- $\quad$ First ideas regarding the sensing approach: Measuring of fatigue through eyes

\section{Intervention capability}

- $\quad$ The mobility device functions as a kind of medical home or indoor fitness device.

- A screen and motion sensor allows for an interactive scenario where the users can play games or follow mobility training instructions.

- Like in a fitness device in a fitness studio, our device shall contain some basic (and modularly separable) physiological sensors on board that allow to monitor the training progress and outcomes.

- $\quad$ First ideas regarding the sensing approach:

- Game controller approach

- Installation of capacitive sensors around the feet which serve both as game controller and as device that can measure muscle strength/contraction

\section{Further requirements/ features}

- $\quad$ The group shall think about solutions that put the user in control over the data: e.g. can the data obtained through monitoring progress be kept on the device only?

- $\quad$ The device shall be made flexible so that it can be easier adjusted to persons of different sizes and thus better circulated between different users.

- $\quad$ Device shall be made mainly for indoor use.

- $\quad$ Device shall fit the door frame width. 
Table 4. Detailing Example; Touchpoint 1 Detailing: Personal Mobility Device (continued)

\section{Development tasks}

- $\quad$ Early detection: INDUSTRY PARTNER2's wearable sensor can be used to deliver raw data (e.g. gyroscope data) - a partner like RESEARCH PARTNER5 and/or RESEARCH PARTNER3 may then develop the detection algorithms > INDUSTRY PARTNER2 will discuss this with RESEARCH PARTNER5. Maybe the ambient sensors can support in providing the for data annotation necessary context.

- $\quad$ Device: INDUSTRY PARTNER4 will mainly take care of the mechanical functions and design of the equipment. RESEARCH PARTNER1 will support with the implementation of the training functions.

- Intervention: RESEARCH PARTNER1 will work on modular add on sensors for obtaining physiological data on the device for progress and usage monitoring. Intervention: RESEARCH PARTNER1 will work on modular add on sensors for obtaining physiological data on the device for progress and usage monitoring.

\section{Primary use case}

- $\quad$ COMMUNITY CENTRE (representing a home or community care use case) is considered as the optimal use case for 'early detection' and light 'intervention/motivation',

- Whereas UNIVERSITY HOSPITAL may be used to evaluate a 'programmed intervention' for more severe cases.

\section{Development roadmap}

- $\quad$ INDUSTRY PARTNER3 will organize a workshop in COUNTRYNAME in June, expected participants: INDUSTRY PARTNER3, RESEARCH PARTNER1, INDUSTRY PARTNER2, Lyngby/ COMMUNITY CENTRE, UNIVERSITY HOSPITAL

- $\quad$ First mock up's to be ready for a consortium internal discussion about testing modalities by mid-summer

\section{Visualization/ guide plan}

Table 5. REACH 'Touchpoint 1 Personal Mobility Device' requirements

HOR002 Touchpoint Personal Mobility Device shall detect early the signs of frailty and the risk of falls

HOR007 Touchpoint Personal Mobility Device shall contain some basic physiological sensors that allow to monitor the training progress and outcomes.

TR002 REACH shall conceptualize the patient journeys and map the issues to the framework

TR005 Touchpoint Personal Mobility Device shall follow the person throughout the patient journey through different care stages

TR006 Touchpoint Personal Mobility Device shall motivate elderly to train themselves, or in a community or together with care personnel in an institution to achieve a better level of mobility

TR007 Touchpoint Personal Mobility Device shall be used as medical home or indoor fitness device

TR008 Touchpoint Personal Mobility Device shall be mobile and compatible with existing furniture

TR009 Touchpoint Personal Mobility Device shall be able to be adjusted in the future to outdoor use through modularity

DMER100 SCs wearable sensor shall deliver raw data and RESEARCH PARTNER5 and/or RESEARCH PARTNER3 shall develop the detection algorithms

SR075 Touchpoint Personal Mobility Device shall provide a screen and motion sensor to allow users to play games and follow mobility training instructions

PIR015 REACH shall analyze the patient-centered process to better conceptualize the services offered PIR013 The planned demonstrations shall make it clear how the proposed ICT solutions enable minimization of risks associated with ageing, as well as enable early detection.

PIR016 REACH shall describe the links with the 'smart furniture'

Table 6. Concept for decomposition of testing approach

\begin{tabular}{|c|c|c|c|c|}
\hline \multicolumn{2}{|c|}{ Touchpoint } & \multicolumn{3}{|c|}{ Testing Instances } \\
\hline Name & Theme & Early Detection & $\begin{array}{c}\text { Motivational } \\
\text { Techniques }\end{array}$ & $\begin{array}{l}\text { Programmed } \\
\text { Interventions }\end{array}$ \\
\hline $\begin{array}{l}\text { TP1 Personal } \\
\text { Mobility Device }\end{array}$ & Frailty and risk of falls & $\begin{array}{l}\text { Hypothesis, outcome } \\
\text { measures, study design }\end{array}$ & $\begin{array}{l}\text { Hypothesis, outcome } \\
\text { measures, study design }\end{array}$ & $\begin{array}{l}\text { Hypothesis, outcome } \\
\text { measures, study design }\end{array}$ \\
\hline $\begin{array}{l}\text { TP2 Active Envi- } \\
\text { ronment }\end{array}$ & Mobility & $\begin{array}{l}\text { Hypothesis, outcome } \\
\text { measures, study design }\end{array}$ & $\begin{array}{l}\text { Hypothesis, outcome } \\
\text { measures, study design }\end{array}$ & $\begin{array}{l}\text { Hypothesis, outcome } \\
\text { measures, study design }\end{array}$ \\
\hline $\begin{array}{l}\text { TP3 Socializing } \\
\text { and Nutrition }\end{array}$ & $\begin{array}{l}\text { Social interaction and } \\
\text { nutrition }\end{array}$ & $\begin{array}{l}\text { Hypothesis, outcome } \\
\text { measures, study design }\end{array}$ & $\begin{array}{l}\text { Hypothesis, outcome } \\
\text { measures, study design }\end{array}$ & $\begin{array}{l}\text { Hypothesis, outcome } \\
\text { measures, study design }\end{array}$ \\
\hline $\begin{array}{l}\text { TP4 Gaming and } \\
\text { Training }\end{array}$ & $\begin{array}{l}\text { General physical and } \\
\text { cognitive ability }\end{array}$ & $\begin{array}{l}\text { Hypothesis, outcome } \\
\text { measures, study design }\end{array}$ & $\begin{array}{l}\text { Hypothesis, outcome } \\
\text { measures, study design }\end{array}$ & $\begin{array}{l}\text { Hypothesis, outcome } \\
\text { measures, study design }\end{array}$ \\
\hline TP5 Wearables & $\begin{array}{l}\text { General physical and } \\
\text { cognitive ability }\end{array}$ & $\begin{array}{l}\text { Hypothesis, outcome } \\
\text { measures, study design }\end{array}$ & $\begin{array}{l}\text { Hypothesis, outcome } \\
\text { measures, study design }\end{array}$ & $\begin{array}{l}\text { Hypothesis, outcome } \\
\text { measures, study design }\end{array}$ \\
\hline
\end{tabular}




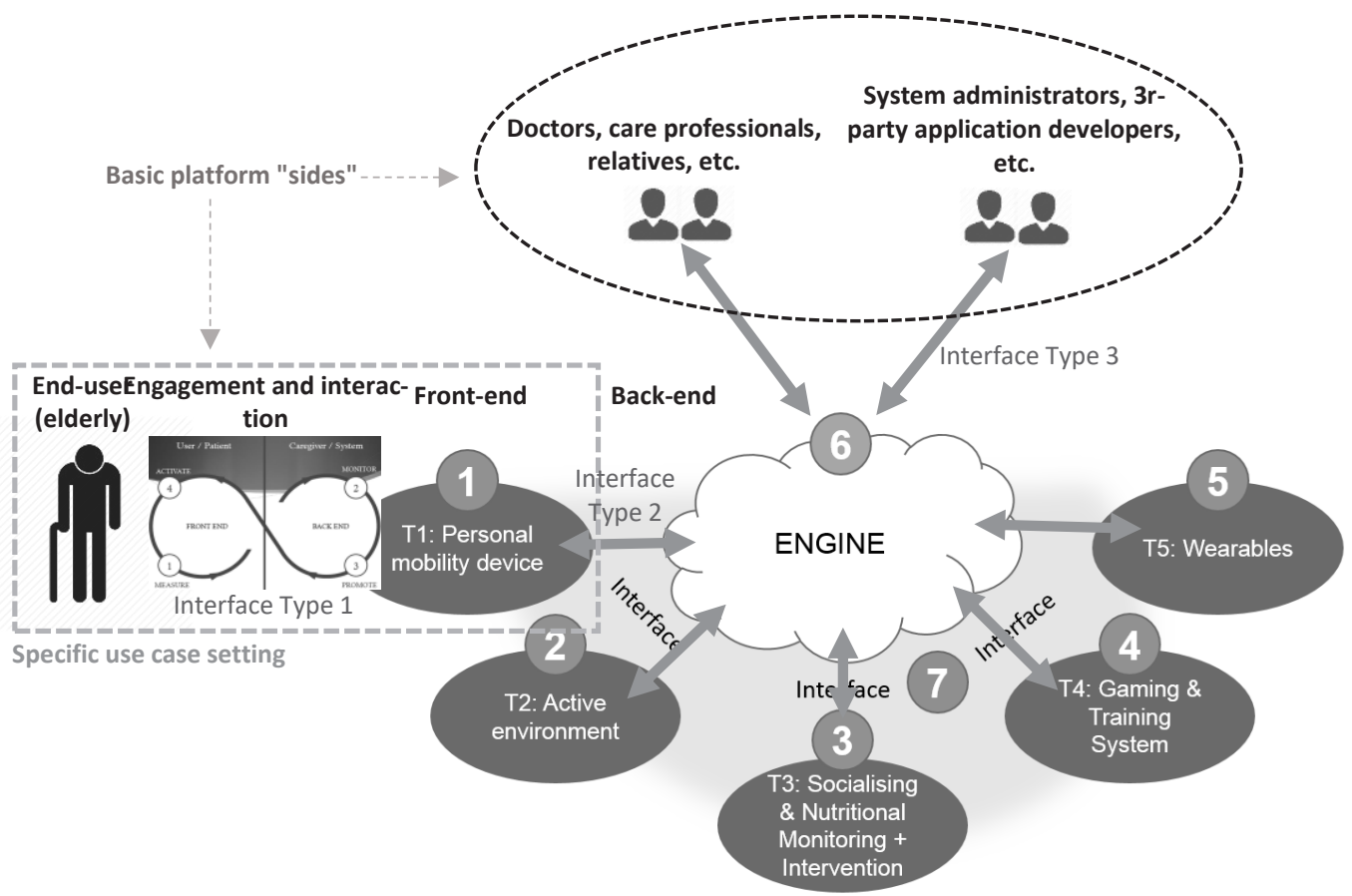

Figure 4. REACH system architecture high-level description

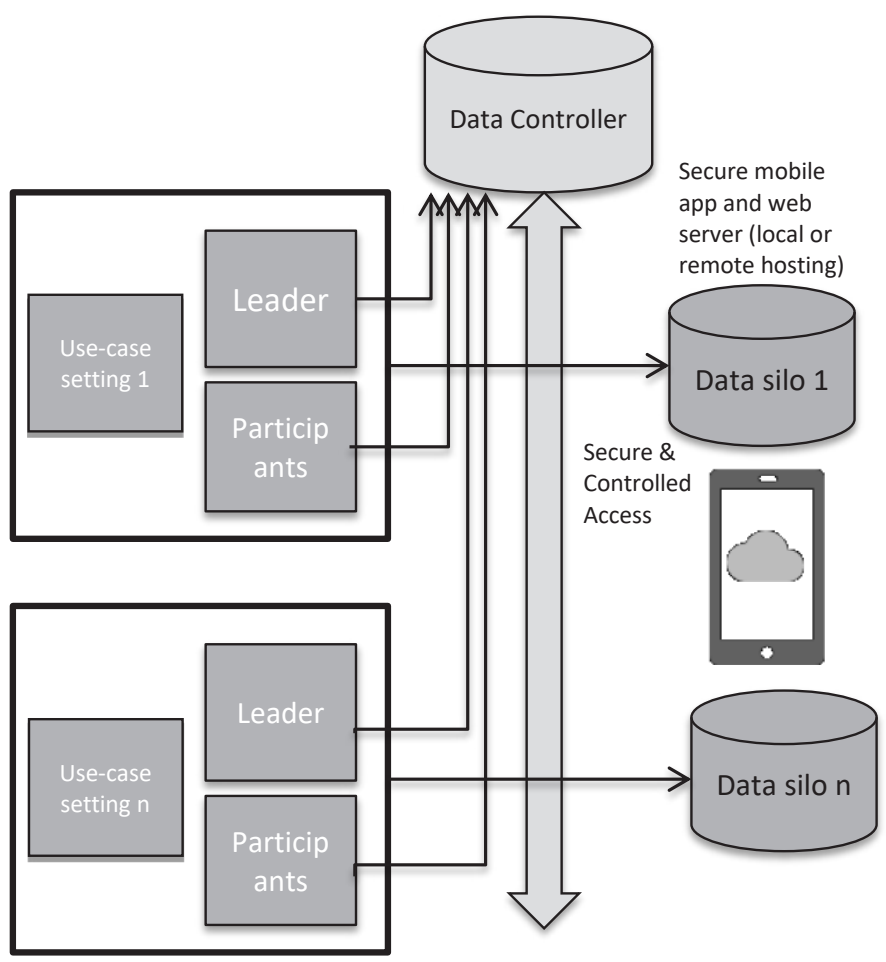

Anonymization wrapper

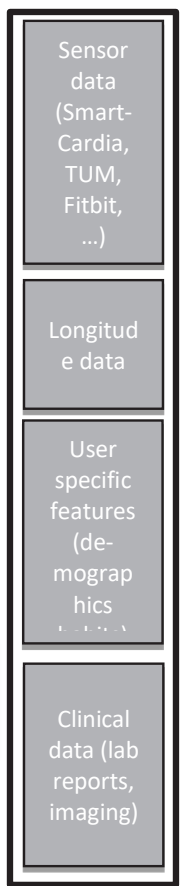

Smart Furniture (=Touchpoints) with ambient and wearable
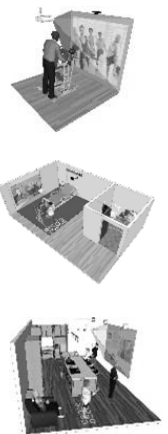

TP3

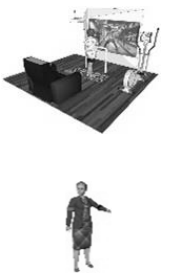

TP4

Figure 5. ICT view-software and data migration architecture, and information flows (Image: INDUSTRY PARTNER2 \& RESEARCH PARTNER1) 
Systems engineering
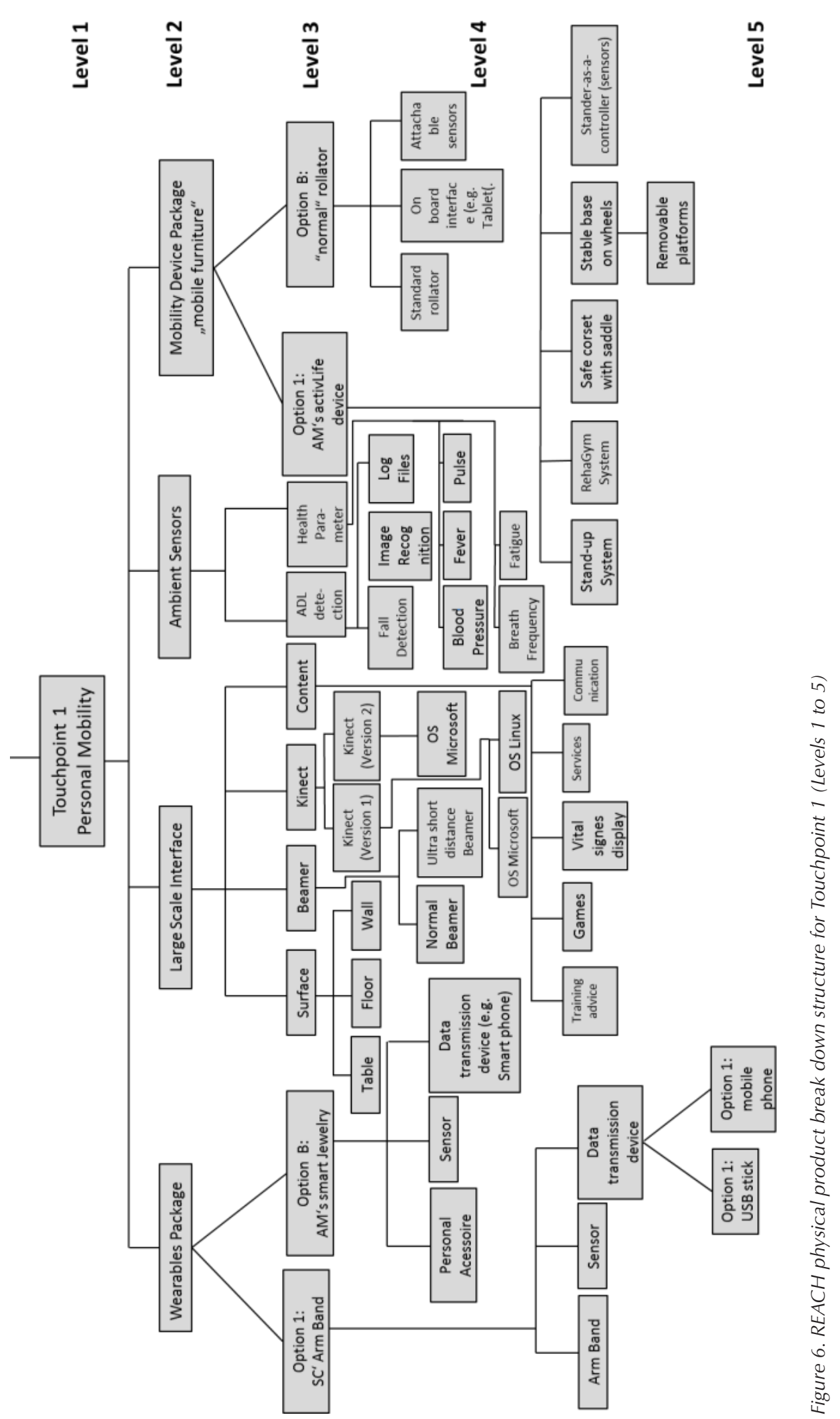
Table 7. Initial detailing of testing approach decomposition scheme; TP1 Personal Mobility Device; Theme: Frailty and risk of falls

\begin{tabular}{|c|c|c|}
\hline Early Detection & $\begin{array}{c}\text { Motivational } \\
\text { Techniques }\end{array}$ & $\begin{array}{l}\text { Programmed } \\
\text { Interventions }\end{array}$ \\
\hline $\begin{array}{l}\text { Signs of frailty and person } \\
\text { under risk of falls; evolu- } \\
\text { tionary approach: early } \\
\text { detection will be done } \\
\text { only with the sensors; } \\
\text { when then risks of falls or } \\
\text { signs of frailty are de- } \\
\text { tected the mobility device } \\
\text { comes in as a safe activa- } \\
\text { tion and training device. }\end{array}$ & $\begin{array}{l}\text { The goal is to motivate the elderly } \\
\text { (e.g. through gamification) to use the } \\
\text { equipment to train a) themselves, b) } \\
\text { or in a community centre for elderly } \\
\text { (e.g. a COMMUNITY CENTRE), or c) } \\
\text { together with care personnel in an } \\
\text { institution to achieve a better level } \\
\text { of mobility. At best, this results in an } \\
\text { improved mobility, e.g. in terms of } \\
\text { distances walked (also without using } \\
\text { the equipment). }\end{array}$ & $\begin{array}{l}\text { The mobility device functions as a } \\
\text { kind of medical home or indoor fit- } \\
\text { ness device. A screen and motion sen- } \\
\text { sor allows for an interactive scenario } \\
\text { where the users can play games or } \\
\text { follow mobility training instructions. } \\
\text { Like in a fitness device in a fitness stu- } \\
\text { dio, our device shall contain some } \\
\text { basic sensors on board that allow to } \\
\text { monitor the training progress. }\end{array}$ \\
\hline
\end{tabular}

with an own hypothesis, own outcome measures, and an instance specific trial design. Table 6 shows the general concept for decomposition of testing approach, and Table 7 shows an initial detailing of testing approach decomposition scheme exemplarily for Touchpoint 1 based on the Touchpoint detailing presented in Section 2.2.

\section{Conclusions}

REACH states a complex system of systems that is not only developed by highly multidisciplinary consortium, but moreover is situated in an environment comprised of a multitude of stakeholders and external systems. Considering later CE certification requirements, it is pertinent to fol- low a structured systems engineering approach even from very early, explorative, and conceptual R\&D or pre-product development phases onwards. In this paper, the key aspects, methods, and tools of this approach are presented, and it is shown how they were used in the concept development stage to systematically translate a variety of inputs and analyses into formalized requirements and a holistic system architecture blue print serving as the basis for further work organization in the project. Finally, a system integration and testing approach could be developed which together with the defined system architecture elements will serve as the basis for further work organization in the project.

\section{Acknowledgements}

This project (and related work) presented in this paper has received funding from the European Union's Horizon 2020 research and innovation programme under grant agreement No 690425. The authors thank the lead partners of work package 1 (RESEARCH PARTNER2, INDUSTRY PARTNER1; the formalization of the system architecture presented in this paper built on the outcomes of the previously conducted co-creation workshops) as well as all use case and technology partners of REACH for their contributions and close cooperation in context of the outlined initial systems engineering phase. The Touchpoint 1 concept which was used in this paper as an example, was developed in close cooperation with INDUSTRY PARTNER3 and the ICT platform view outlined in Figure 5 with INDUSTRY PARTNER2. The complementary testing approach outlined in Chapter 4 was developed in close cooperation with RESEARCH PARTNER4.

\section{References}

1. Harer J. Anforderungen an Medizionprodukte. München: Hanser GmbH 2014; https://doi. org/10.3139/9783446440210

2. InLoox. Agile Project Management Methods: With reliable flexibility to project success: A guide on agile project management and how it helps you achieve

great things at work; https://www.inloox.com/agileproject-management/; retrieved April 4, 2017

3. Moran A. Managing Agile: Strategy, Implementation, Organisation and People. Heidelberg: Springer International Publishing 2015; pp 187-208; https://doi.org/10.1007/978-3-319-16262-1_10

4. NASA. NASA Systems Engineering Handbook 2007, https://www.google.de/url?sa=t\&rct=j\&q=\&esrc= $\mathrm{s} \&$ source $=$ web\&cd $=1 \&$ ved $=0$ ahUKEwijx 7 Ttt_zSA hXLWSwKHfahCVkQFggoMAA\&url=http $\% 3 \mathrm{~A} \%$ 2F\%2Figs.nigc.ir\%2FSTANDS\%2FBOOK\%2FHBNASA.PDF\&usg=AFQjCNEqquFnlx1L9irCl3XApi6 Fq9s2kA\&cad=rja; retrieved April 4, 2017

5. Nicholls G, Lewis N, Eschenbach T. Determining when simplified Agile Project Management is right for small teams. Engineering Management Journal 2015;27(1):3-10; https://doi.org/10.1080/10429247. 2015.11432031

6. Osborne L, Brummond J, Hart R, Zarean M, Conger, S. Clarus: Concept of Operations 2005; https:// ntl.bts.gov/lib/jpodocs/repts_te/14158_files/14158. pdf; retrieved April 4, 2017

7. Sparx Systems. Enterprise Architect; http://www. sparxsystems.com/; retrieved March 26, 2017

8. VersionOne. Agile Project Management: Agile Project Management Done Right!; https://www. versionone.com/agile-project-management/; retrieved April 4, 2017 